\title{
肺転移能を有するヒト上顎癌細胞株の樹立と性状
}

\author{
五十嵐丈人1) ・宮田守1)・森田守1) \\ 中村 良博2) - 園田 哲史 ${ }^{3)}$
}

\section{Establishment and Characterization of Human Maxillary Cancer Cell Line (MMSI-1)}

\author{
Masahito Igarashi, Mamoru Miyata and Mamoru Morita \\ (Jichi Medical School) \\ Yoshihiro Nakamura \\ (Teikyo University) \\ Tetsushi Sonoda \\ (Sonoda ENT Clinic)
}

\begin{abstract}
The human maxillary cancer cell line, MMSI-1, was established from the xenograft which was implanted in nude mice and had been maintained for more than five years. Its characteristics were examined, MMSI-1 showed stable growth and the population doubling time was 1.9 days. Intravenous injection of MMSI-1 tumor cells produced lung metastases in nude mice. Southern blot hybridization showed seven-fold c-myc amplification ; there was no overexpression of N-myc, erb B and erb B2. The lysate of MMSI-1 cells shortened the plasma recalcification time, but no thromboplastic activity was found in this lysate.

There has been no previous report on human head and neck cell lines which can metastasize to the lung by intravenous inoculation of cancer cells. Therefore, the most conspicuous property of MMSI-1 seemed to be its metastasizing ability.
\end{abstract}

Key words: human cell line, maxillary cancer, lung metastasis, c-myc-gene

はじめに

近年ヒトの癌細胞の培養株化は各科領域で盛 んに行われ，その生物学的特性に関する検討や， 化学療法の効果判定などについて多くの研究が なされている．また，原発巣の治療成績の向上 に伴い，遠隔転移の制御が問題となりつつある 現在, 培養細胞株と実験動物を用いた転移モデ
ルについての報告もなされるようになった．頭 頸部領域に执いても細胞株樹立についての報告 は散見され，上顎癌についても本邦でもいくつ かの報告がある ${ }^{1) ~ 5) . ~}$

今回我々は，ヒト上顎扁平上皮癌を培養株化 し，その特性の検討を行った。この細胞株 (MMSI-1) の注目すべき特徵は, ヌードマウス

1) 自治医科大学耳鼻咽喉科学教室

2) 帝京大学医学部耳鼻咽喉科学教室

3）園田耳鼻咽喉科（東京都） 
への静注により肺に転移巣を形成することであ

る. 頭頸部領域においては培養細胞を用いた転 移に関する報告は，検索し得た範囲では認めら れず, MMSI-1 はマウスー人癌系の人工転移モ デルとして有用と思われる.

\section{材料および方法}

(1)細胞株の樹立：1985年10月，52歳の女性の 上顎腫瘍 (低分化型扁平上皮癌) の生検標本 (図 1) の一部を $\mathrm{BALB} / \mathrm{c} \mathrm{nu} / \mathrm{nu}$ マウス（ヌード マウス）の背部皮下に移植した. 以後腫瘍の増 大に応じてヌードマウスでの継代を繰り返し， 4 代目になった腫瘍を用いて初代培養を試みた。 初代培養は, $10 \mathrm{~cm}$ の plastic dish に約 $1 \mathrm{~mm}$ 角に切った腫瘍塊を静置し，15\% FCS 加 RPMI1640を培養液として加光， $5 \% \mathrm{CO}_{2}, 37$ ${ }^{\circ} \mathrm{C}$ の条件下で行った．継代は dish に付着性に 増殖した細胞を，0.1\%EDTA Na 加トリプシ ンで浮遊させて行った。

な捻患者は, 手術, 放射線療法, 化学療法に ても原発巣を制御できず死亡した。臨床的には 遠隔転移は認めなかった（剖検は施行せず）.

(2)増殖能 : $2 \times 10^{5}$ 個の細胞を $3.5 \mathrm{~cm}$ plastic dish に植光込み，24時間ごとに 4 日間まで dish の細胞数を計測して増殖曲線を作成し， 倍加時間を算出した。

(3)形態学的観察 : 培養細胞は位相差倒立顕微 鏡で観察した。また， $6 \times 10^{5}$ 個の細胞をヌー ドマウスの皮下に移植して腫瘤を形成させ，

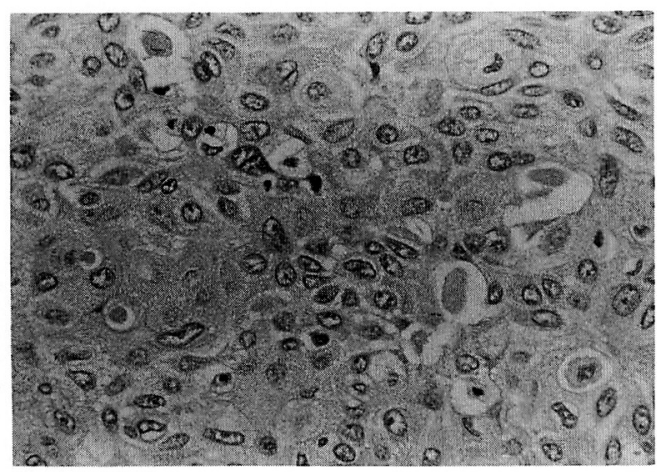

図 1 上顎からの生検標本 $(\mathrm{HE}$ 染色 $\times 400)$
HE 染色標本にて患者から得た生検標本と比較 した.

(4)血液凝固能: MMSI-1の細胞浮遊液を作成 し，これを凍結，融解して超音波処理を行い， 遠沈，滤過することにより腫瘍抽出液を得た。 抽出液の作成法は，Kinjo6）らの方法によった。 この抽出液を用いて血小板凝集能とカルシウム 再加時間を測定した．血小板凝集能は Payton lumiaggregation model を用いて測定した. 血 漿カルシウム再加時間は, 正常者血清 $0.1 \mathrm{ml}$ に腫瘍抽出液 $0.1 \mathrm{ml}$ (対照では生食 $0.1 \mathrm{ml}$ )を 加光 $37^{\circ} \mathrm{C}$ で 5 分放置した後 $25 \mathrm{mMCaCl}_{2}$ を加 えて測定した。

(5)癌遺伝子の増幅 : N-myc, c-myc, erb B, erb B2 について増幅の有無を検討した. 癌遺 伝子の測定は, Southern blot 法により SRL 遺 伝子検查ラボラトリーで行われた.

(6)肺転移形成能 : $1 \times 10^{6}$ 個 $/ 0.2 \mathrm{ml}$ の細胞浮 遊液を作製し，これをマウスの尾静脈より静注 した. 1 力月後に動物を屠殺して肺を摘出し, 転移巣の形成の有無を HE 染色標本で観察した。 マウスは BALB/c nu/nu（ヌードマウス）(57 匹), C57 BL/6 (30匹), C57 BL/6 beige ( 5

匹）の 3 種を用いた.

結 果

(1)細胞株の樹立 : 静置した腫瘍片の周辺より

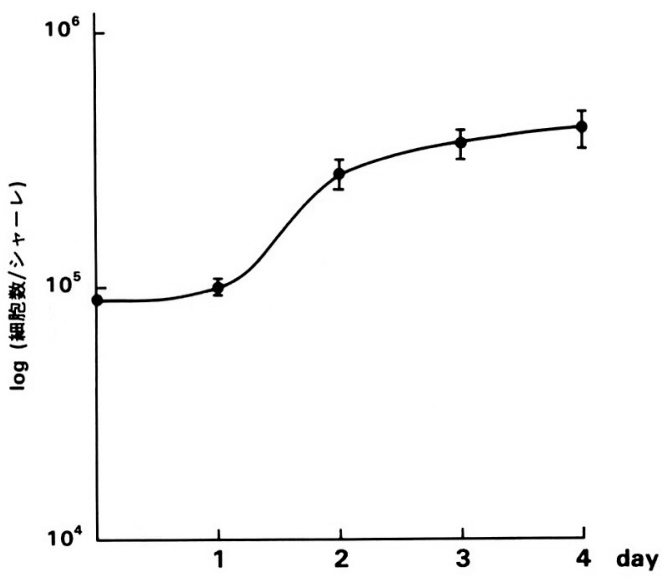

図 2 growth curve 
腫瘍細胞の増殖がみられた。 fibroblast の混入 はほとんどなかった．安定した継代が可能で， 現在までの継代数は201代（5 年 6 カ月）であ る.

(2)増殖能：growth curve は図 2 に示したと

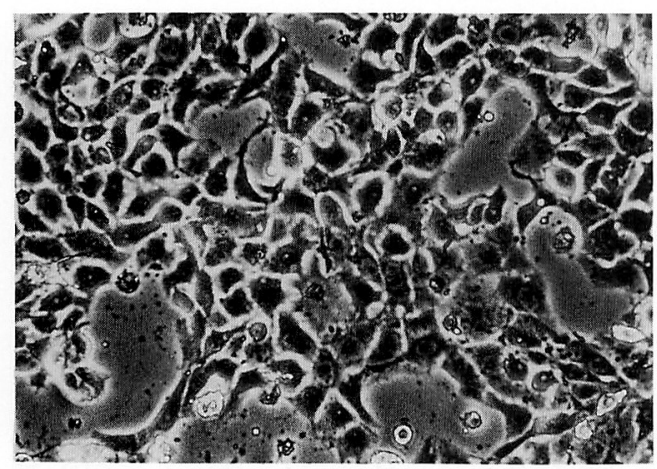

図 3 倒立顕微鏡像 $(\times 100)$

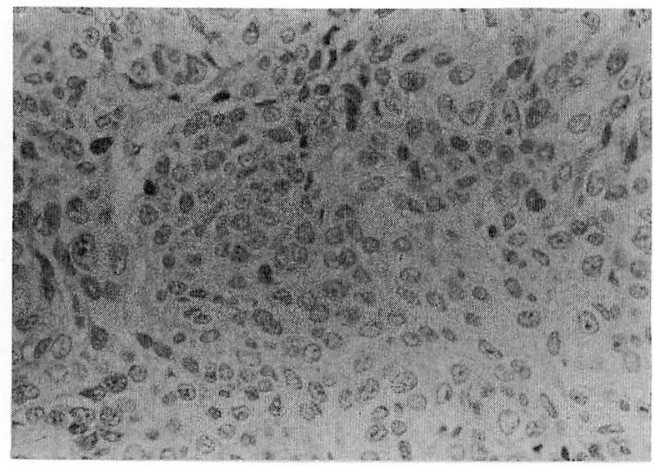

図 4 ヌードマウス皮下の腫瘍 $(\mathrm{HE}$ 染色 $\times 400)$

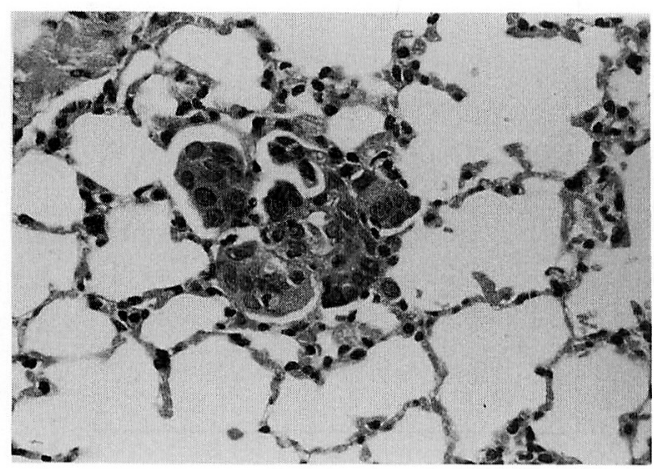

図 5 肺転移像 $(\mathrm{HE}$ 染色 $\times 400)$
おりである。倍加時間は1.9日であった。

(3)形態学的観察 : 位相差倒立顕微鏡による観 察では, 細胞は plastic dish に付着性に敷石状 に増殖し，大小不同の核と明瞭な核小体を有す る多角形の細胞であった（図 3 ）。ヌードマウ スに移植して形成された腫瘍は低分化型扁平上 皮癌の像を示し, 原発腫瘍の形態を維持してい た（図 4 ).

(4)血液凝固能 : 腫瘍抽出液による血小板の凝 集は認められなかった。 カルシウム再加時間は 対照群 147.2 秒に対し腫瘍抽出液を加光ると 24.0 秒となり, 内因系凝固因子の活性化が認め られた。

(5)癌遺伝子の増幅 : c-myc で対照群に対し 7 倍の増幅が認められた. N-myc, erb B, erb B2 では遺伝子の増幅はみられなかった。

(6)肺転移形成能 : C57 BL/6 および C57 BL/ 6 beige マウスでは肺に転移巣はみられなかっ た. BALB/c nu/nu ヌードマウスでは56匹中 9 匹に転移が認められた。図 5 に肺転移巣の $\mathrm{HE}$ 染色像を示す.

\section{考察}

現在マウスを用いた遠隔転移の実験モデルと しては，癌細胞を皮下に移植してその後の転移 をみる方法, 癌細胞の脾臓内注入により門脈を 経由した血行性肝転移を観察する方法, 癌細胞 を直接静脈内へ注入して各臓器に転移を形成さ せる方法などが知られている，皮下腫瘍からの 転移は自然転移モデルであり, 後 2 者は人工転 移モデルである．用いられるマウスは細胞がヒ ト由来の場合はヌードマウスが多く，また C57 $\mathrm{BL} / 6$ とその同系の腫瘍を用いた報告も多い.

悪性腫瘍の遠隔転移は, 癌細胞の増殖および 血管の新生 $\rightarrow$ 母腫瘍塊からの血管やリンパ管 への腫瘍細胞の遊離 $\rightarrow$ 脈管内移動 $\rightarrow$ 転移蔵器 の毛細血管床への定着 $\rightarrow$ 血管内皮細胞への付 着 $\rightarrow$ 血管外への遊出 $\rightarrow$ 増殖の開始と栄養血管 の新生といら一連の過程を経て完成されるもの であり7)，自然転移モデルはこのすべての転移 形成の過程を含九で拈り理想的である。ヌード 
マウスは種々のヒト由来の癌細胞が高率に生着 して腫瘤を形成するため，一見容易に自然転移 モデルとして利用できそうに思われる。しかし ヌードマウスでの移植腫瘍の自然転移形成率は 非常に低いとされている. Sharkey 58) の報告 では, 106種のヒトの癌細胞株を1045匹のヌー ドマウスの皮下に移植したところ，転移をきた したのはわずか11株14匹（1.3\%）であり，頭 頸部癌は 3 株52匹すべてで転移を認めなかった. in vitro での培養細胞を用いると転移率は高く なるといわれる9)がそれほど高率ではなく，そ の上頭頸部癌では in vitro での株化そのものが むずかしいといら問題もある，自然転移をおこ す細胞株の樹立についての報告は散見されるよ らになったが，その数は少なく，頭頸部領域で の報告はないようである。一方, 腫瘍細胞の静 注による転移形成は，母腫瘍塊から腫瘍細胞が 脈管内に移行した後の経過をみることになる. しかし短期間で結果が得られ，細胞が体内に散 布される時期や腫瘍細胞の量, 質などの条件を 容易に一定にすることができ，この方法を利用 しての多くの研究報告がなされている. 本法も マウスー人癌系の一つの転移モデルとして確立 された方法となっている.

MMSI-1 の転移形成率は高いとはいえないが， 我々は，実際にこの細胞株を用いて転移形成率 が抗癌剤の投与により変化する傾向があるなど の実験結果を得て招り10)11), 転移に対する化学 療法の効果などを検討していく上で有益なモデ ルと思われる。

ヌードマウスに転移が执きにくい理由はいま だ明確にされていない. NK 細胞活性が高いこ とが要因の一つと考えられている12) 15) が，腫 瘍の進展状態, 個々の腫瘍細胞の持つ固有の転 移能, 腫瘍がヒト由来で recipient がマウスで あることなど NK 活性以外にも種々の要因が あるとされている819). 我々は $\mathrm{NK}$ 活性の異な る 3 種類のマウス, すなわち, NK 活性の正常 対照として C57 BL/6 マウスを用い，これより $\mathrm{NK}$ 活性の高い $\mathrm{BALB} / \mathrm{c} \mathrm{nu} / \mathrm{nu}$ ヌードマウス,
さらに, $\mathrm{NK}$ 活性の低い $\mathrm{C} 57 \mathrm{BL} / 6$ beige マウ スを用いて肺転移の形成率を検討した。この結 果ヌードマウスにのみ転移巣がみられたことか ら，NK 活性以外にも転移に関わる重要な要因 が存在することが類推された.

転移に関連する因子として血小板凝集能をは じめとする血液凝固能も重要である. 腫瘍細胞 は血小板と凝集塊をつくることにより局所への 定着が容易になり，さらに血小板から放出され る増殖因子が転移巣の発育を助けることが予想 される.MMSI-1の腫瘍抽出液を用いた実験で は血小板凝集能は認められなかったが, 癌細胞 の血小板凝集能は主に細胞膜にあるとされてお り16)17)，腫瘍抽出液では膜成分の多くが除去さ れていることが原因と思われた．しかし腫瘍抽 出液を用いたカルシウム再加時間の検討では著 明な短縮が認められ, 内因系凝固因子の活性化 が示唆された。これは MMSI-1 の静注直後の 肺の組織所見で肺内の毛細血管内に著明な血栓 の形成が認められた所見と一致し10111), 凝固系 への影響が転移巣形成に大きく関係しているこ とが推測される。

癌遺伝子は腫瘍の増殖や転移に関係する重要 な要因として近年研究が進んできている．転移 能との関係が報告されている癌遺伝子には $\mathrm{N}-$ myc, c-myc, erb B, ras, fos などがあるが, MMSI-1 では c-myc の増幅がみられた. myc 遺伝子は神経細胞由来の悪性腫瘍での増幅が多 いとされ, 神経芽細胞腫, 網膜芽細胞腫, 肺の 小細胞癌などでの増幅が報告されている. 扁平 上皮癌についても, 子宮頸癌に执いて, c-myc の増幅が遠隔転移の重要な危険因子であるとの 報告が最近なされており 18 興味深い。

\section{まとめ}

1 ）静注により肺転移をきたすとト上靧扁平 上皮癌細胞株 MMSI-1 の樹立とその性状につ いて報告した. 本腫瘍は人工転移のモデルとし て有用と思われた。

2) 肺転移は C $57 \mathrm{BL} / 6$ および $\mathrm{C} 57 \mathrm{BL} / 6$ beige マウスではみられず， ヌードマウスのみ 
に認められた。

3 ) 癌遺伝子 c-myc の増幅が認められた.

4) MMSI-1 の腫瘍抽出液は血小板凝集能を 欠いていたが，カルシウム再加時間の短縮から 内因系凝固因子の活性化が示唆された。

$$
\text { 文献 }
$$

1）石田 稔：人癌細胞の培養 一上靧癌由来の細 胞株について一. 日耳鼻 $81: 588 \sim 603,1978$.

2) Nakashima $T$, Makishima $K$ and Hiroto $I$ : Establishment of a new cell line from maxillary sinus carcinoma. Ann Otol Rhiol Laryngol $89: 24 \sim 28,1980$.

3）猪川 勉: 頭頸部扁平上皮癌細胞に対する自己 リンパ球の細胞障害性の研究 -1 頭頸部扁平 上皮癌細胞の培養一. 日耳鼻 $84: 1571 \sim 1578$, 1981.

4）高橋光明, 熊井恵美, 金井直樹, 他 : 七上上顎 癌培責細胞の細胞特性. 日耳鼻 $90: 21 \sim 27$, 1987.

5）久保田彰：上龥癌初代培養株による制癌剤感受 性試験の基礎的研究.耳鼻 $34: 309 \sim 321,1988$.

6) Kinjo $M$, Oka K, Kohga $S$, et al : Thromboplastic and fibrinolytic activities of cultured human cancer cell lines. Br J Cancer 39 : 15 23, 1979.

7) Poste G and Fidler IJ : The pathogenesis of cancer metastasis. Nature $283: 139 \sim 146,1980$.

8) Sharkey FE and Fogh J : Metastasis of human tumors in athymic nude mice. Int J Cancer $24: 733 \sim 738,1979$.

9) Kozlowski JM, Fidler IJ, Campbell D, et al : Metastatic behavior of human tumor cell lines grown in the nude mouse. Cancer Res 44 : 3522 3529, 1984.

10）宮田 守, 西野 宏, 五十風丈人, 他: 頭頸部 癌培着細胞株を用いた肺転移に関する実験的研
究. 頭頸部腫瘍 $17: 30 \sim 36,1991$.

11) Igarashi $M$, Miyata $M$, Morita $M$, et al : Fate of human maxillary cancer cells injected intravenously and trapped in the lung of mice. 日癌治 $26: 243,1991$.

12) Hanna $N$ and Schneider $M$ : Enhancement of tumor metastasis and suppression of natural killer cell activity by $\beta$-estradiol treatment. J Immunol $130:$ 974 980, 1983.

13) Hanna $\mathrm{N}$ and Fidler IJ : Role of natural killer cells in the destruction of circulating tumor emboli. JNCI $65: 801 \sim 809,1980$.

14) Talmadge JE, Meyers KM, Prieur DJ, et al : Role of natural killer cells in tumor growth and metastasis ; $\mathrm{C} 57 \mathrm{BL} / 6$ normal and beige mice. JNCI $65:$ 929 935, 1980.

15) Hanna $\mathrm{N}$ and Fidler IJ : Expression of metastatic potential allogenic and xenogeneic neoplasms in young nude mice. Cancer Res $41: 438 \sim 444,1981$.

16) Honn KV, Onoda JM, Menter PG, et al : Platelet-tumor cell interactions as a target for antimetastatic therapy. Mechanisms of cancer metastasis (ed by Honn KV, Powers WE and Sloane BF). pp 117 144, Martinus Nijhoff Publishing, Boston, 1986.

17）新津洋司郎, 茂木良弘, 坂内 清, 他: 七上癌 細胞培養株による血小板凝集に関する研究. 癌 と化学㙩法 11 : 480 486, 1984.

18) Bourhis J, Lê MG, Gerbaulet D, et al : Prognostic value of c-myc protooncogene overexpression in early invasive carcinoma of the cervix. J Clin Oncol 8 : 1789 1796, 1990.

$$
\left(\begin{array}{c}
\text { 別刷請求先 : 五十嵐丈人 } \\
\mathbf{\mathbf { T }} 329-04 \\
\text { 栃木県河内郡南河内町 } \\
\text { 薬師寺3311-1 } \\
\text { 自治医科大学耳鼻咽喉科学教室 }
\end{array}\right)
$$

